\title{
OPTIMALISASI FUNGSI KEPALA RUANGAN DALAM PENETAPAN JADWAL DINAS PERAWAT BERBASIS KOMPETENSI: PILOT STUDY
}

\author{
Ichsan Rizany ${ }^{1}$, Tutik Sri Hariyati ${ }^{2}$, Sri Purwaningsih ${ }^{3}$ \\ ${ }^{1}$ Mahasiswa S-2 Kepemimpinan dan Manajemen Keperawatan, \\ Fakultas IImu Keperawatan, Universitas Indonesia \\ ${ }^{2}$ Dosen S-2 Kepemimpinan dan Manajemen Keperawatan, Fakultas Ilmu Keperawatan, \\ Universitas Indonesia \\ ${ }^{3}$ Manajer Keperawatan Rumah Sakit Umum Pusat Persahabatan \\ E-mail: ichsan.r.psik@gmail.com
}

\begin{abstract}
ABSTRAK
Tujuan penelitian: melakukan pemberdayaan fungsi kepala ruangan dalam implementasi jadwal dinas berbasis kompetensi di rumah sakit umum vertikal kelas $A$ yang menjadi rumah sakit pusat rujukan nasional. Metode: pendekatan pilot studi yang dilaksanakan dari analisis situasi, pembuatan plan of action, implementasi, evaluasi dan analisis gap menggunakan literatur review. Pilot studi dilakukan selama \pm 7 minggu kepada 43 perawat dan 16 kepala ruangan sebagai responden. Analisis situasi dilakukan dengan menggunakan diagram fish bone. Hasil: Masalah utama ialah belum optimalnya pelaksanaan jadwal dinas berbasis kompetensi. Implementasi yang dilakukan ialah brainstorming kepada kepala ruangan tentang pentingnya kompetensi dalam pelaksanaan jadwal dinas dan melakukan uji coba jadwal dinas berbasis kompetensi. Hasil uji coba didapatkan bahwa $100 \%$ kepala ruangan merasa jadwal dinas berbasis kompetensi lebih efektif. Hasil kuesioner menunjukkan adanya peningkatan pengetahuan kepala ruangan tentang pentingnya kompetensi dalam penjadwalan perawat menjadi 8,6 dan rata-rata penilaian diri (self asessment) dari kepala ruangan tentang evaluasi pembuatan jadwal dinas berbasis kompetensi sebesar 7,88 dari 10 poin. Pelaksanaan penjadwalan berbasis kompetensi mendapat hambatan berupa kurangnya jumlah tenaga perawat, karakteristik perawat, dan pemerataaan kompetensi. Simpulan: pemberdayaan fungsi kepala ruangan dalam implementasi jadwal dinas berbasis kompetensi lebih efektif dan memudahkan pekerjaan kepala ruangan dalam pengaturan jadwal dinas. Peran kepala ruangan sangat penting dalam pembuatan jadwal dinas berbasis kompetensi. Peran kepala bidang keperawatan sangat membantu sistem jadwal dinas dengan membuat kebijakan yang tepat dan sejalan dengan misi pelayanan keperawatan untuk memberikan pelayanan berkualitas dan aman.

Kata Kunci: jadwal dinas, kompetensi, perawat.
\end{abstract}

\section{OPTIMIZATION THE FUNCTION OF THE HEAD NURSE IN DETERMINING COMPETENCE- BASED NURSE SERVICE SCHEDULE: A PILOT STUDY ABSTRACT}

Objective: To empower the function of head nurse in implementing competence-based nurse service schedule in grade A hospital which serves as a national referral hospital. Methods: This study employed a pilot study approach that was performed in situation analysis, making of Plan of Action, implementation, evaluation and gap analysis using literature review. The pilot study was conducted for approximately 7 weeks to 43 nurses and 16 head nurses as respondents. The situation analysis was performed using fishbone diagram. Results: The main problem was unoptimal implementation of competence-based nurse service schedule. The implementation done was brainstorming to the head nurses about importance of competence in the implementation of service schedule and conducting trial of the competence-based nurse service schedule. The trial results indicated that $100 \%$ of the head nurses thought that the competence-based nurse service schedule was more effective. The questionnaire results indicated increased head nurses' knowledge of the importance of competence in nurse scheduling by 8.6, and average self-assessment of the head nurses on the evaluation of competency-based nurse service scheduling by 7.88 out of 10 points. The implementation of competence-based scheduling was obstructed by lack of the number of nurses, characteristics of nurses and even distribution of competence. Conclusion: The empowerment of the function of head nurses in the implementation of competence-based nurse service schedule was more effectively and could facilitate the work of head nurses in managing the service schedule. The 
role of head nurses was very important in competence-based nursing service scheduling. The role of head nurses was useful in nurse service schedule system by making appropriate policy and was in line with the mission of nursing care in providing quality and safe service.

Keywords: nurse scheduling, competence, nurse

\section{LATAR BELAKANG}

Pelayanan keperawatan memberikan kontribusi terbanyak dalam pelayanan di rumah sakit. Pelayanan keperawatan dilaksanakan selama 24 jam dengan pembagian shift 3 kali sehari/7 hari (Lieder dkk., 2015). Pelayanan keperawatan dilakukan dengan memberikan asuhan keperawatan kepada masyarakat sesuai dengan kaidah profesi perawat dengan memperhatikan kompetensi yang sesuai dengan jenjang karier perawat (Kuokkanen, dkk., 2016). Pelayanan keperawatan yang tidak kompeten akan berdampak pada pasien sehingga pelayanan keperawatan dituntut memiliki kualitas dan mutu yang baik.

Pelayanan keperawatan yang berkualitas menuntut seorang manajer untuk bertanggung jawab menjalankan fungsi dan perannya. Lima fungsi manajer keperawatan dimulai dari planning, organizing, staffing, actuating, dan controlling (ArmstrongStassen, dkk., 2015). Manager keperawatan juga diharapkan menjalankan interpersonal roles, informational roles, dan decisional roles (Whitehead dkk., 2007).

Manajer juga dituntut mampu mengelola penjadwalan perawat dengan baik. Penjadwalan adalah pengaturan dan pengalokasian waktu perawat yang tersedia untuk melakukan tugas yang sudah direncanakan dengan tujuan untuk meminimalkan biaya dan pemerataan beban kerja (Legrain dkk., 2015; Lin dkk., 2015). Penjadwalan yang dibuat secara tepat oleh manajer akan meningkatkan kepuasan kerja (Simunić dan Gregov, 2012; Wright dan Mahar, 2013; Koning,
2014; Stimpfel dkk., 2015; Leineweber dkk., 2016), memberikan ikatan sosial yang erat (Farasat dan Nikolaev, 2016), memengaruhi kualitas perawatan dan moral perawat dalam memberikan pelayanan (Tsaia dan Leeb, 2010), serta mempertahankan retensi perawat dan menurunkan konflik dengan keluarga (Okonkwo, 2014).

Penjadwalan perawat juga akan berdampak terhadap pasien. Penelitian Trinkoff dkk. (2011) menyebutkan bahwa penjadwalan perawat memiliki efek independen terhadap mortalitas pasien. Pasien akan merasa puas jika perawat yang memberikan pelayanan keperawatan memiliki kinerja yang tepat sesuai kompetensi.

Kompetensi adalah kemampuan perawat untuk melakukan tugasnya melalui aspek pengetahuan, sikap, keterampilan, dan berpikir kritis (Chang dkk., 2011; Satu dkk., 2013). Kompetensi perawat akan memengaruhi faktor pekerjaan lain seperti kinerja, kepuasan dan penjadwalan perawat, dan absensi perawat (Numminen dkk., 2015; Kuokkanen dkk., 2016). Oleh karena itu, kompetensi diakui menjadi faktor penting untuk memastikan pelayanan keperawatan yang berkualitas.

Kompetensi perawat belum sepenuhnya diperhatikan oleh manajerdalam penjadwalan perawat. Kompetensi perawat di Indonesia dihubungkan dengan jenjang karier perawat klinik (PK I s/d PK V) yang setiap jenjang memiliki kewenangan klinis (Hariyati dkk., 2016). Seharusnya setiap perawat bekerja sesuai kewenangan klinis untuk memberikan perawatan yang berkualitas. 
Fenomena ini ternyata masih didapati di rumah sakit umum di Jakarta. Di rumah sakit umum vertikal dengan kelas $A$ yang menjadi rumah sakit pusat rujukan (top referral) nasional juga belum melaksanakan jadwal dinas berbasis kompetensi walaupun rumah sakit sudah melaksanakan jenjang karier dan bekerja sama dengan Japan International Cooperation Agency (JICA) untuk mengembangkan proses jenjang karier keperawatan tesebut. Pelaksanaan dalam jadwal dinas perawat juga belum semuanya memperhatikan skill mix perawat. Pelaksanaanjadwaldinaslebih diorientasikan kepada proses mengisi jumlah tenaga. Selain itu, belum tersedia standard operating procedure (SOP) jadwal dinas berbasis kompetensi. Berdasarkan latar belakang tersebut, penulis tertarik untuk melakukan perubahan untuk mengoptimalkan fungsi kepala ruangan dalam penetapan jadwal dinas perawat berbasis kompetensi di rumah sakit kelas $A$.

\section{Sikap Perawat terhadap Jadwal Dinas Berbasis Kompetensi di RSUP $X$ November $2016(n=43)$}

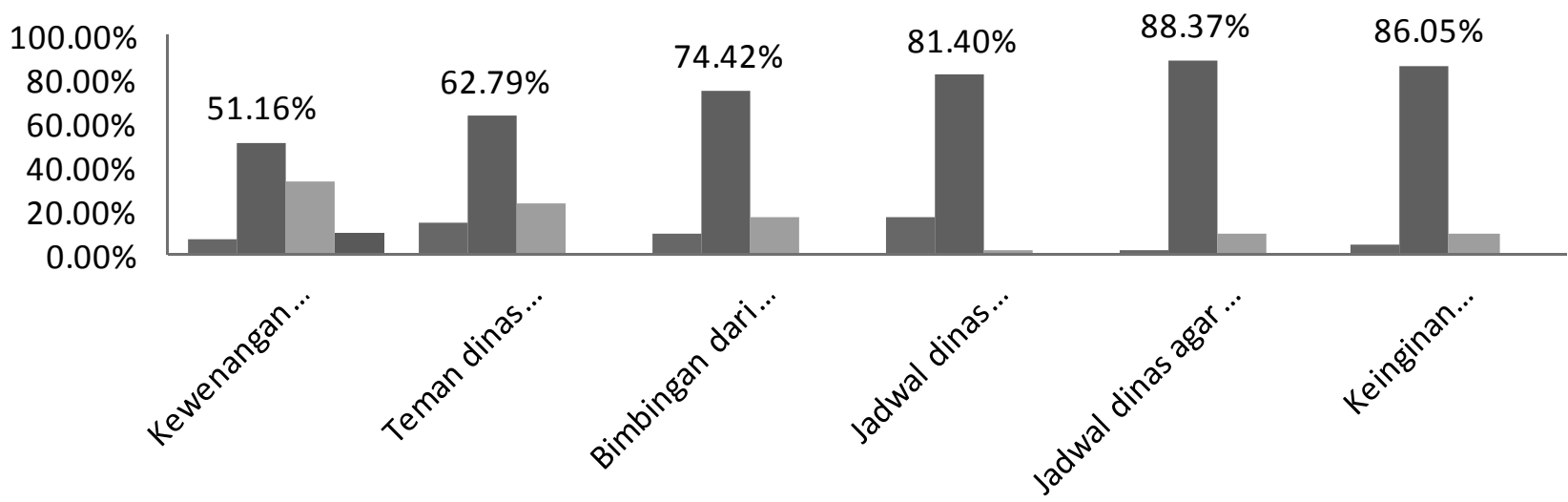

Gambar 1. Sikap Perawat terhadap Jadwal Dinas Berbasis Kompetensi di RSUP X November $2016(n=43)$

\section{METODE}

Metode yang digunakan dalam kegiatan agen pembaharu terkaitjadwal dinas berbasis kompetensi ini adalah menggunakan pendekatan pilot study. Metode ini dimulai dari analisis situasi, pembuatan plan of action (POA), implementasi, evaluasi, dan analisis gab menggunakan literature review. Pengambilan sampel menggunakan tehnik sampling random untuk pemilihan ruangan dilanjutkan dengan tehnik purposive sampling untuk menentukan sampel perawat dan kepala ruangan. Pilot studi dilakukan selama \pm 7 minggu kepada 43 perawat dan
16 kepala ruangan. Sistem pengambilan pilot study menggunakan homogenitas dengan ruangan yang menerapkan siklus shift.

$$
\text { Instrumen pengambilan data }
$$

menggunakan wawancara, observasi, studi dokumen, dan kuesioner. Wawancara dan observasi dilakukan kepada kepala bidang keperawatan dan kepala ruangan, sedangkan kuesioner dibagikan kepada perawat di ruangan. Data awal diambil dari 8 ruangan. Ruangan tersebut menjadi perwakilan dari setiap unit terkait. Analisis situasi dilakukan dengan menggunakan diagram fishbone (Gambar 2) dengan menganalisis penyebab 
masalah yang meliputi man, method, machine, material, dan money. Implementasi untuk penyelesaian masalah diselesaikan dengan menggunakan proses PDCA (plan do check action) yang dimulai dari penetapan rencana, implementasi, evaluasi, dan rencana tindak lanjut. Perencanaan ditetapkan untuk mengoptimalkan fungsi kepala ruangan dalam membuat jadwal dinas berbasis kompetensi. Implementasi untuk mengoptimalkan pemahaman kepala ruangan tentang pembuatan jadwal dinas berbasis kompetensi dilakukan dengan memberikan brainstorming kepada kepala ruangan dan dilanjutkan dengan uji coba di masing-masing ruangan. Proses evaluasi dari implementasi dilakukan menggunakan kuesioner dan observasi untuk mengetahui keberhasilan atau hambatan dalam proses pelaksanan. Hasil evaluasi dianalisis secara deskriptif untuk melihat gap yang terjadi saat pelaksanaan dengan membandingkan dari literatur.

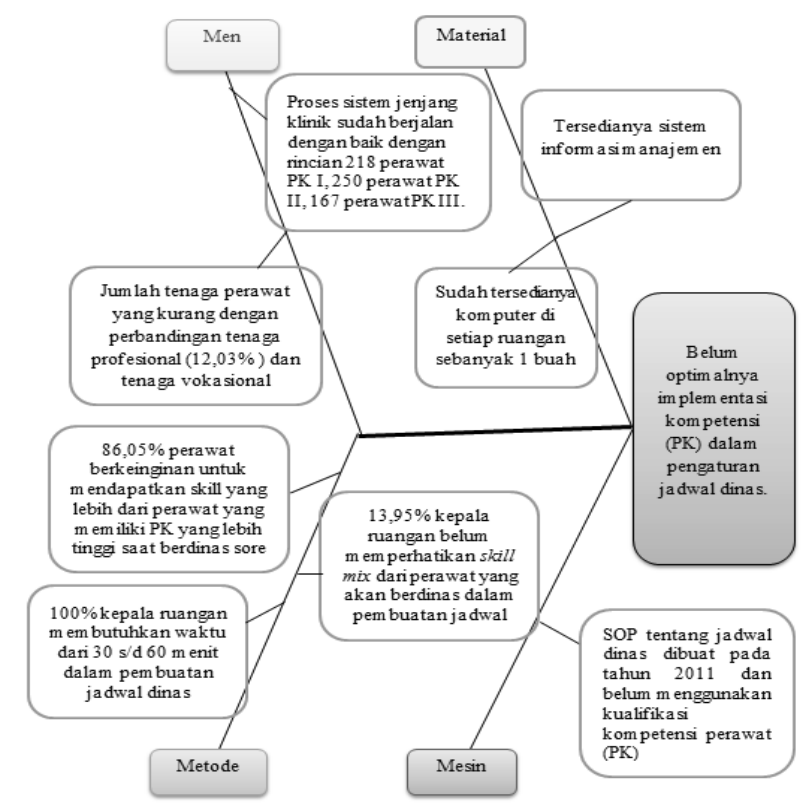

Gambar 2. Diagram fishbone

\section{HASIL}

Hasil analisis situasi sebelum dilakukan implementasi dapat dilihat pada Gambar 1 yang menunjukkan bahwa 88,37 persen perawat ingin pembuatan jadwal dinas memperhatikan PK berjenjang dan 86,05 persen perawat ingin mendapatkan skill yang lebih dari perawat yang memiliki PK lebih tinggi saat berdinas sore atau malam. Hasil ini menjadi salah satu bagian dari analisis fishbone. Beberapa faktor penyebab lainnya yang telah diidentifikasi oleh penulis ditulis dalam bentuk diagram fishbone yang dapat dilihat pada Gambar 2.

Gambar 2 menunjukkan belum optimalnya implementasi kompetensi dalam pengaturan jadwal dinas. Faktor penyebab dari bagian metode memberikan penegasan bahwa kompetensi dalam jadwal dinas belum mendapatkan perhatian oleh kepala ruangan sebesar 13,95 persen. Selain itu, tingginya keinginan perawat untuk mendapatkan bimbingan dari PK menjadi pendorong untuk dilakukan perubahan sebesar 86,05 persen. 
Kegiatan dari agen perubahan dilakukan melalui brainstorming kepada kepala ruangan. Brainstorming bertujuan untuk meningkatkan pemahaman kepala ruangan tentangpentingnyaimplementasijadwaldinas berbasis kompetensi sehingga keinginan dari perawat untuk bisa mendapatkan bimbingan dari perawat dengan PK yang lebih tinggi terlaksana. Hasil yang didapatkan sebelum dan sesudah brainstorming dapat dilihat dalam Gambar 3.

Gambar 3 menunjukkan bahwa pemahaman kepala ruangan tentang pentingnya kompetensi dalam jadwal dinas mengalami peningkatan setelah dilakukan implementasi berupa brainstorming menjadi 8,6 . Materi brainstorming yang diberikan kepada kepala ruangan tentang pentingnya kompetensi dan fungsi kepala ruangan dalam jadwal dinas.

Implementasi yang dilakukan oleh penulis untuk mengoptimalkan fungsi kepala ruangan dalam pembuatan jadwal dinas berbasis kompetensi dibuat menjadi sebuah alur atau skema untuk mempermudah kepala ruangan. Alur tersebut dapat dilihat pada Gambar 4.

Gambar 4 menunjukkan bahwa alur kebijakan dibuat berdasarkan panduan jadwal dinas yang menjelaskan setiap langkah yang harus dilakukan dalam setiap kondisi. Pelaksanaan jadwal dinas berbasis kompetensi juga didukung dengan adanya SOP_SOP sehingga lebih memperkuat kebijakan demi memberikan keselamatan pasien seutuhnya melalui perawatan profesional yang memperhatikan kompetensi perawat.

Prosesujicobapelaksanaanoptimalisasi fungsi kepala ruangan dalam pembuatan jadwal dinas juga dilakukan evaluasi. Hasil evaluasi didapatkan rata-rata penilaian kepala ruangan tentang pelaksanaan jadwal dinas berbasis kompetensi ini sebesar 7,88 dari 10. Penilaian ini menunjukkan bahwa kepala ruangan memberikan penerimaan positif untuk melakukan perubahan dalam jadwal dinas. Selain itu, hasil evaluasi juga menilai tingkat keberhasilan dan hambatan yang bisa dilihat pada Tabel 1.

Tabel 1. Evaluasi uji coba

\begin{tabular}{clc}
\hline No & Pernyataan & Persentase \\
\hline 1 & $\begin{array}{l}\text { Kepala ruangan menilai jadwal dinas berbasis kompetensi lebih efektif dan } \\
\text { memudahkan pekerjaan dalam jadwal dinas }\end{array}$ & 100 \\
2 & $\begin{array}{l}\text { Kepala ruangan menyebutkan bahwa jadwal dinas berbasis kompetensi akan } \\
\text { mampu dilaksanakan atau diterapkan di rumah sakit }\end{array}$ & 100 \\
3 & $\begin{array}{l}\text { Kepala ruangan menyebutkan kurangnya tenaga baik segi jumlah dan } \\
\text { pemerataan kompetensi di unit }\end{array}$ & 100 \\
4 & $\begin{array}{l}\text { Kepala ruangan menyebutkan ego perawat menjadi hambatan dalam } \\
\text { pembuatan jadwal dinas berbasis kompetensi }\end{array}$ \\
\hline
\end{tabular}

Tabel 1 menunjukkan bahwa hasil berupa ego perawat yang tidak bisa diatur implementasi dari pelaksanaan jadwal dinas dan belum merata jumlah tenaga sesuai berbasis kompetensi berjalan dengan baik kompetensi di ruangan.

walaupun mendapat hambatan-hambatan 


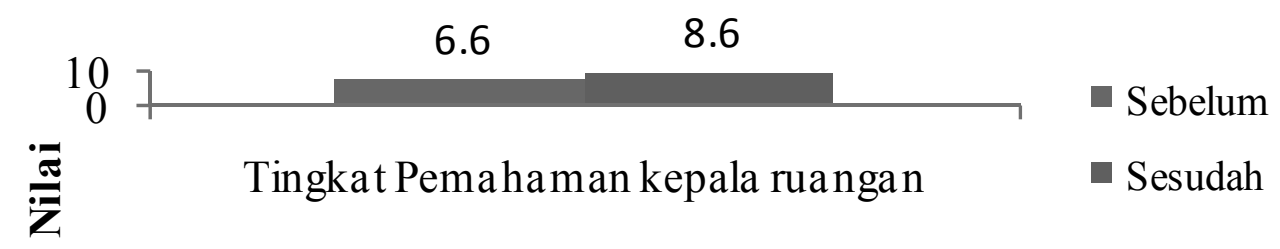

Gambar 3. Hasil evaluasi brainstorming berupa penilaian tingkat pemahaman kepala ruangan tentang pentingnya kompetensi dalam jadwal dinas.

\section{DISKUSI}

Hasil dari agen perubahan untuk mengoptimalkan fungsi kepala ruangan dalam pembuatan jadwal dinas berbasis kompetensi mendapatkan dukungan dan antusiasme yang tinggi dari kepala ruangan. Hal ini dapat dilihat dari hasil yang telah didapatkan bahwa pemahaman kepala ruangan meningkat setelah dilakukan brainstorming. Kemudian, 100 persen kepala ruangan menilai jadwal dinas berbasis kompetensi lebih efektif dan memudahkan pekerjaan dalam jadwal dinas serta penilaian kepala ruangan tentang pelaksanaan jadwal dinas berbasis kompetensi ini sebesar 7,88.

Pelaksanaan brainstorming dirasakan efektif dalam memberikan pemahaman baru tentang pentingnya penjadwalan dinas berbasis kompetensi kepada kepala ruangan. Brainstorming digunakan untuk meningkatkan pemahaman kepala ruangan dengan menghilangkan asumsi lama dan memberikan solusi baru (Allen dkk., 2013). Brainstorming adalah metode untuk menilai kebutuhan menggunakan ide-ide yang dihasilkan oleh kelompok tanpa kritik atau komentar sebanyak solusi yang diperlukan (DeSilets, 2007).

Alur yang telah dibuat memberikan gambaran kepada kepala ruangan dalam mengimplementasikan jadwal dinas berbasis kompetensi. Alur yang dibuat tersusun dan menguraikan kebijakan-kebijakan yang akan dijalankan oleh kepala ruangan sehingga pelaksanaan akan lebih efektif. Pembuatan kebijakan yang tepat dan efektif akan membantu kepala ruangan dalam bekerja. Penelitian Gonela, dkk. (2013) menegaskan bahwa kebijakan penjadwalan yang efektif akan secara signifikan membantu masalah dalam proses pelayanan keperawatan salah satunya mengurangi hasil pelaporan waktu lab (LRRT) dan tingkat stres perawat.

Pelaksanaan penjadwalan dinas berbasis kompetensi di unit yang dilakukan oleh kepala ruangan terbukti efektif dan memudahkan pekerjaan. Hasil ini juga sejalan dengan penelitian Harper dkk. (2009) yang menyebutkan bahwa penyebaran kompetensi untuk perawat di setiap shift dapat memberikan efisiensi dan efektivitas untuk pelayanan keperawatan di rumah sakit. Penelitian lainnya oleh Duffield dkk. (2010) mempertegas bahwa pelayanan keperawatan yang berkualitas dapat diperoleh dengan cara menyebarkan perawat dengan kompetensi yang berbeda secara merata di setiap shift sehingga asuhan keperawatan dapat berjalan secara optimal.

Kepala ruangan juga mendapatkan hambatan dalam uji coba jadwal dinas berbasis kompetensi. Ada beberapa faktor yang memengaruhi proses pelaksanaan kompetensi dalam jadwal dinas. Jumlah tenaga keperawatan menjadi masalah utama dalam pembuatan jadwal dinas berbasis kompetensi. Hal ini sejalan dengan penelitian Moore dan Waters (2012) yang menyebutkan bahwa jumlah perawat yang 
kurang akan menyebabkan beban kerja perawat meningkat sehingga perawat tidak lagi melaksanakan tindakan sesuai kompetensi yang dimiliki perawat. Aiken dkk. (2012) mempertegas bahwa peningkatan lingkungan kerja dan mengurangi rasio pasien kepada perawat akan meningkatkan kualitas pelayanan dan kepuasan pasien. Selain itu, menurut Trinkoff, dkk. (2011), jumlah tenaga yang kurang tidak dibenarkan untuk melakukan pelayanan yang lama karena akan berdampak terhadap perawatan dan dapat meningkatkan potensi kesalahan oleh perawat. Oleh karena itu, pembuatan jadwal dinas berbasis kompetensi dengan tenaga keperawatan yang kurang menjadi kendala utama dalam pelaksanaan penjadwalan.

Karakteristik perawat juga menjadi penghambat kedua yang ditemukan dalam implementasi jadwal dinas berbasis kompetensi. Hal ini sejalan dengan penelitian De Causmaecker dan Vanden Berghe (2011) yang menyebutkan bahwa karakteristik perawat mempengaruhi dalam membuat jadwal dinas. Selain itu, ego dari senior (senioritas) dalam penjadwalan dinas perawat juga masih ada sehingga senior mempunyai perlakuan khusus untuk menentukkan jadwal yang fleksibel (Van Den Bergh dkk., 2013). Hal ini menyebabkan ada penolakan secara tidak langsung oleh perawat senior untuk mengimplementasi jadwal dinas berbasis kompetensi.

Faktor lainnya yang menghambat proses implementasi kompetensi dalam jadwal dinas ialah pemerataan kompetensi dari tenaga perawat. Kompetensi yang dimiliki setiap perawat di ruangan seharusnya berbeda-beda dan berjenjang dengan memperhatikan masa kerja dan pendidikan sehingga setiap pengaturan jadwal dinas perawat terlaksana skill mix di setiap shift. Hal ini juga sejalan dengan penelitian Takase dkk. (2014) yang menyebutkan bahwa kompetensi dipengaruhi oleh pengalaman kerja dan pendidikan. Kedua aspek ini menjadi hambatan dalam pemerataan SDM di beberapa ruangan sehingga tidak bisa dijalankan dengan optimal.

Selain itu, Maenhout dan Vanhoucke (2009) menegaskan bahwa komposisi perawat dari segi kompetensi harus berbedabeda sehingga kepala perawat harus memperhatikan kompetensi dan skill mix staf di ruangan. Selain itu, penelitian Harper dkk. (2009) menunjukkan bahwa tingkat yang lebih tinggi pada perawat memiliki dampak positif kepada hasil perawatan pasien dan angka kematian terbukti lebih rendah, yakni pasien dirawat dengan pemerataan level perawat yang optimal.

Perawat yang telah memiliki kualifikasi kompetensi bekerja sesuai dengan surat penugasan kewenangan klinik yang telah didapat. Perawat dengan kualifikasi kompetensi mendapat pandangan dari masyarakat bahwa perawat mempunyai kompetensi yang baik (Garside dan Nhemachena, 2013). Masyarakatmempunyai harapan bahwa kompetensi perawat mampu memberikan pelayanan yang berkualitas. Pelayanan yang berkualitas bisa diberikan oleh perawat melalui penjadwalan dinas.

Penjadwalan perawat dibuat oleh kepala ruangan sebagai manajer bawah. Kepala ruangan harus memahami pembuatan jadwal dinas yang baik sehingga akan memberikan manfaat untuk organisasi. Penjadwalan perawat juga akan memberikan manfaat untuk meningkatkan kepuasan kerja, mempertahankan retensi perawat, menurunkan konflik dengan keluarga, memberikan ikatan sosial yang erat (Simunić dan Gregov, 2012; Koning, 2014; Leineweber dkk., 2016; Farasat dan Nikolaev, 2016).

Pengaturan jadwal mampu memberikan kepuasan kepada perawat. Hasil penelitian Diaz dkk. (2010) menunjukkan bahwa 
kepuasan perawat diperoleh melalui pengaturan jadwal yang fleksibel. Penelitian Nelson dan Tarpey (2010) mempertegas bahwa keseimbangan kehidupan juga meningkat dengan adanya jadwal yang fleksibel. Selain itu, manajemen jadwal dinas dengan shift dan hari off yang tepat memungkinkan perawat untuk mengambil istirahat untuk meningkatkan kualitas pelayanan.

Penjadwalan perawat juga akan berdampak terhadap pasien baik secara langsung maupun tidak langsung. Penelitian Trinkoff, dkk., 2011 menunjukkan hasil bahwa penjadwalan perawat memiliki efek independen terhadap mortalitas pasien. Penjadwalan perawat juga memengaruhi kualitas perawatan dan moral perawat (Tsaia dan Leeb, 2010). Pasien akan merasa puas jika perawat yang memberikan pelayanan keperawatan memiliki kinerja yang tepat sesuai kompetensi.

Manajer yang bertanggung jawab membuat jadwal dinas harus memperhatikan beberapa hal agar pelaksanaan jadwal dinas berjalan dengan baik, meliputi: 1) waktu fleksibel; 2) staf tidak boleh lelah berlebihan karena seringnya atau permintaan lembur yang memanjang; 3) asuhan pasien tidak boleh terganggu; 4) pengambilan keputusan dalam jadwal dinas harus memperhatikan kebijakan yang berlaku di organisasi; 5) mengupayakan keadilan dalam pembuatan jadwal dinas; 6) kepersonalian siklik, yaitu diketahui jadwal kerja selanjutnya karena pola kepersonalian berulang setiap empat minggu sekali; 7) pemanfaatan kepersonalian tambahan kepersonalian; 8) kompetensi perawat yang telah ditentukan oleh kebijakan rumah sakit; 9) penjadwalan yang dilakukan sendiri oleh staf; 10) skill mix perawat (Kim dan Windsor, 2015; Maenhout dan Vanhoucke, 2009; Marquis dan Huston, 2012; Okonkwo, 2014; Trinkoff, dkk., 2011;
Wright dan Mahar, 2013).

Skill mix penting untuk dijalankan dalam pelayanan keperawatan. Manajer harus memperhatikan skill perawat yang bertujuan agar keilmuan perawat bisa selalu berkembang dengan adanya bantuan dari perawat yang lebih tinggi kompetensinya. Penelitian Duffield dkk. (2010) menyebutkan bahwa skill mix memberikan waktu untuk berlatih dengan perawat yang lain. Selain itu, skill mix dan kompetensi dilakukan untuk memberikan pelayanan yang berkualitas dengan berfokus kepada pasien sehingga pasien akan merasa aman. Penelitian Hayes (2012) menyebutkan bahwa skill mix dan rasio sama-sama penting, tetapi manajer yang hanya peduli dengan rasio tidak memberikan perawatan yang ideal dan pelayanan berkualitas. Hasil penelitian Profesor Griffi THS yang dikutip oleh Moore dan Waters (2012) menegaskan bahwa skill mix yang lebih kaya mungkin lebih hemat biaya dan investasi untuk mempekerjakan perawat RN menjadi strategi biaya yang efektif dibandingkan dengan karyawan lain yang lebih murah.

Implementasi kompetensi dalam jadwal dinas juga tidak terlepas dari kinerja manajer untuk menjalankan fungsi dan perannya di pelayanan keperawatan. Seorang manajer bertugas untuk memberikan motivasi, pemikiran, dan pengaturan untuk mencapai tujuan melalui orang lain (Miyata dkk., 2015). Manajer keperawatan menjalankan lima fungsi POSAC dimulai dari planning, organizing, staffing, actuating, dan controlling (Armstrong-Stassen, dkk., 2015). Menurut Mintzberg dalam Robbins dan Judge (2013), peran manajer dalam menjalankan manajemen di organisasi pelayanan keperawatan meliputi peran interpersonal, peran informasional dan peran memutuskan. Pada hakikatnya, fungsi manajer ialah melakukan manajemen pelayanan dari 
perencanaan sampai pengendalian sehingga keperawatan tetap selalu melaksanakan diharapkan mampu melakukan inovasi atau fungsi pengarahan (actuating) untuk perubahan dalam pelayanan keperawatan. memandu organisasi dalam mencapai

Keberhasilan dalam pelaksanaan tujuan yang spesifik (MacLeod, 2012). inovasi dan program tidak terlepas dari Pengarahan dilakukan melalui supervisi, peran manajer keperawatan dari bidang komunikasi, kolaborasi dan koordinasi, keperawatan sampai kepala ruangan. manajemen konflik, dan pemberian motivasi Peran manajer tetap penting dalam terhadap kepala manajer lini bawah (kepala mengimplementasikan jadwal dinas berbasis ruangan) (Marcella-Brienza dan Mennillo, kompetensi walaupun panduan dan SOP 2015; Miltner dkk., 2015; Mokoka dkk., 2010; sudah tersedia. Top manager atau bidang Schwarzkopf dkk., 2011).

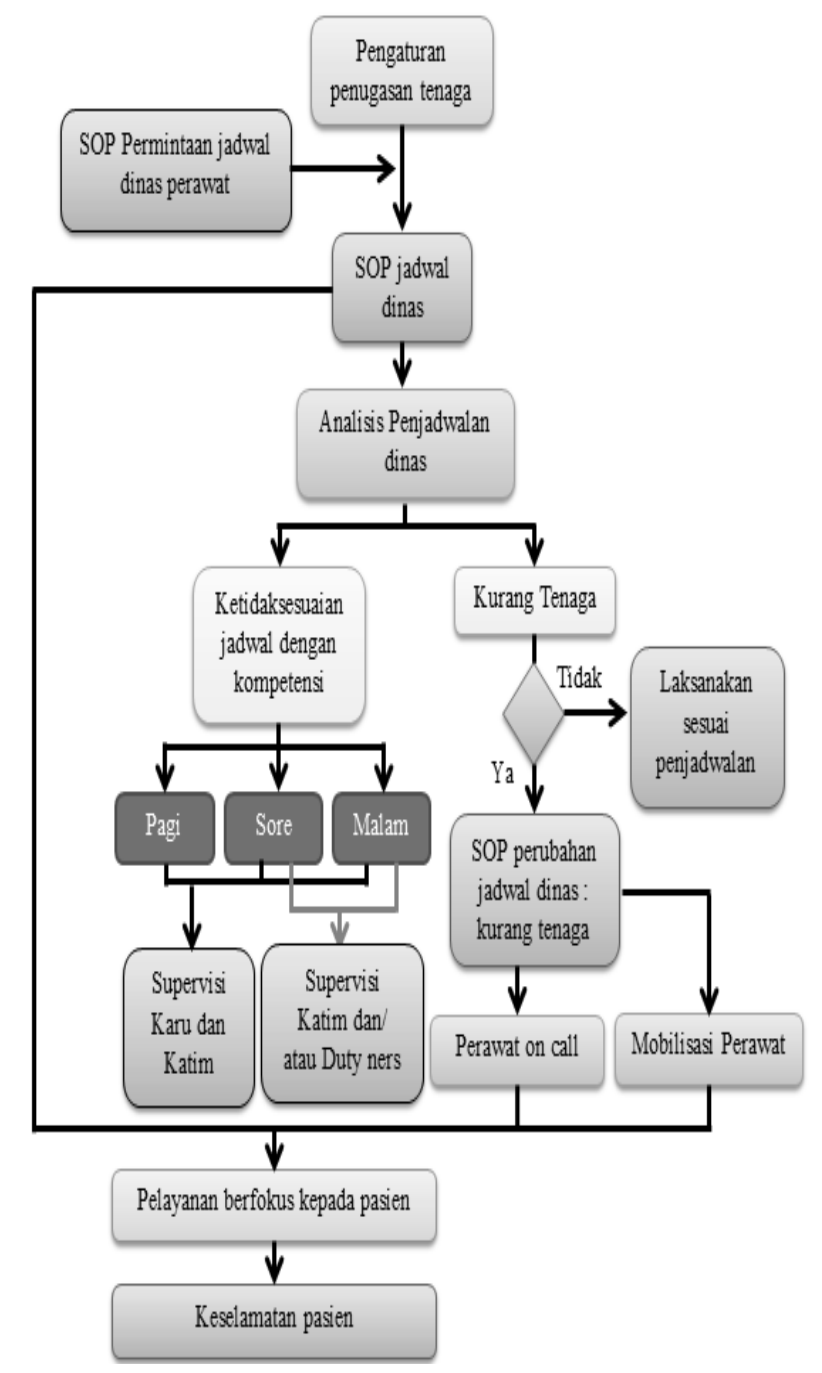

Gambar 4. Alur kebijakan jadwal dinas berbasis kompetensi 


\section{SIMPULAN}

Hasil uji coba didapatkan bahwa jadwal dinas berbasis kompetensi lebih efektif dan memudahkan pekerjaan kepala ruangan dalam pengaturan jadwal dinas. Rata-rata penilaian kepala ruangan tentang pelaksanaan jadwal dinas berbasis kompetensi ini sebesar 7,88 dari 10 . Selanjutnya, pemahaman kepala ruangan tentang pentingnya kompetensi dalam jadwal dinas meningkat dari 6,6 menjadi 8,6. Optimalisasi fungsi kepala ruangan dalam penetapan jadwal dinas perawat berbasis kompetensi sudah berjalan dengan baik walaupun mendapat hambatan berupa kurangnya jumlah tenaga perawat, karakteristik perawat, dan pemerataaan kompetensi.

Peran manajer sangat penting dalam pengaturan dan pembuatan jadwal dinas berbasis kompetensi. Dalam menjalankan sistem jadwal dinas berbasis kompetensi, manajer keperawatan harus mengupayakan pemerataaan jumlah tenaga sesuai dengan jumlah pasien dan pemerataan kualifikasi perawat (PK) di setiap ruangan. Peran kepala bidang (top manager) sangat membantu sistem jadwal dinas ini jika kebijakan yang dibuat tepat, efektif, dan sejalan dengan misi pelayanan keperawatan untuk memberikan pelayanan berkualitas dan aman kepada pasien.

\section{DAFTAR PUSTAKA}

Aiken, L. H., Sermeus, W., Van den Heede, K., Sloane, D. M., Busse, R., McKee, M., Kutney-Lee, A. 2012. "Patient Safety, Satisfaction, and Quality of Hospital Care: Cross Sectional Surveys of Nurses and Patients in 12 Countries in Europe and the United States". BMJ (Clinical Research Ed.), 344(March), e1717. http://doi.org/10.1136/bmj.e1717
Allen, P. E., Keough, V. A., \& Armstrong, M. L. (2013). "Creating Innovative Programs for the Future". J. Nurs Educ, 52(9), 486491. http://doi.org/10.3928/0148483420130819-05

Armstrong-Stassen, M., Freeman, M., Cameron, S., dan Rajacich, D. 2015. 'Nurse Managers' Role in Older Nurses' Intention to Stay". Journal of Health Organization and Management, 29(1), 55-74. http://doi.org/10.1108/JHOM-022013-0028

Chang, M. J., Chang, Y. J., Kuo, S. H., Yang, Y. H., dan Chou, F. H. 2011. "Relationships Between Critical Thinking Ability and Nursing Competence in Clinical Nurses". Journal of Clinical Nursing, 20(21-22), 3224-3232. http://doi.org/10.1111/ j.1365-2702.2010.03593.x

De Causmaecker, P. dan Vanden Berghe, G. 2011. "A Categorisation of Nurse Rostering Problems". Journal of Scheduling, 14(1), 3-16. http://doi. org/10.1007/s10951-010-0211-z

De Silets, L.D. 2007. "Needs Assessments: An Array of Possibilities". The Journal of Continuing Education in Nursing, 38(3), 107-112.

Diaz, D.M., Erkoc, M., Asfour, S. S., dan Baker, E. K. 2010. "Journal of Advances in Management Research New Ways of Thinking about Nurse Scheduling". Journal of Advances in Management Research Iss Journal of Health Organization and Management International Journal of Health Care Quality Assurance Iss Journal of Health Organization and Management Journal of Advances in Management Research, 7(1), 76-93. http://doi. org/10.1108/09727981011042865

Duffield, C., Roche, M., Diers, D., CatlingPaull, C., dan Blay, N. 2010. "Staffing, Skill Mix and the Model of Care". Journal 
of Clinical Nursing, 19(15-16), 2242$2251 . \quad$ http://doi.org/10.1111/j.13652702.2010.03225.x

Farasat, A. dan Nikolaev, A.G. 2016. "Signed Social Structure Optimization for Shift Assignment in the Nurse Scheduling Problem". Socio-Economic Planning Sciences. $\quad$ http://doi.org/10.1016/j. seps.2016.06.003

Garside, J. R. dan Nhemachena, J. Z. Z. 2013. "A Concept Analysis of Competence and Its Transition in Nursing". Nurse Education Today, 33(5), 541-545. http:// doi.org/10.1016/j.nedt.2011.12.007

Gonela, V., Zhang, J., Osmani, A., Awudu, I., Farahmand, K., dan Shi, J. 2013. "Designing Effective and Efficient Scheduling Policy to Improve Laboratory Performance". IIE Annual Conference and Expo 2013, 1449-1459.

Hariyati, R.T.S., Sutoto, dan Irawaty, D. 2016. Kredensial dan Rekredensial Keperawatan. Rajawali Pers, Jakarta.

Harper, P.R., Powell, N.H., dan Williams, J. E. 2009. "Modelling the Size and SkillMix of Hospital Nursing Teams". Journal of the Operational Research Society, 61(5), 768-779. http://doi.org/10.1057/ jors. 2009.43

Hayes, N. 2012. "One Nurse to Seven Older Patients: RCN Recommends A Safe Staff Ratio". Nursing Standard, 26(29), 12-13.

Kim, M. dan Windsor, C. 2015. "Resilience and Work-Life Balance in First-Line Nurse Manager". Asian Nursing Research, 9(1), 21-27. http://doi.org/10.1016/j. anr.2014.09.003

Koning, C. (2014). Does self-scheduling increase nurses' job satisfaction? An integrative literature review. Nursing Management, 21(6), 24-28. http://doi. org/10.7748/nm.21.6.24.e1230
Kuokkanen, L., Leino-Kilpi, H., Numminen, O., Isoaho, H., Flinkman, M., dan Meretoja, R. 2016. "Newly Graduated Nurses' Empowerment Regarding Professional Competence and Other Work-Related Factors". BMC Nursing, 15(1), 22. http://doi.org/10.1186/s12912016-0143-9

Legrain, A., Bouarab, H., dan Lahrichi, N. 2015. "The Nurse Scheduling Problem in Real-Life". Journal of Medical Systems, 39(1), 160. http://doi.org/10.1007/ s10916-014-0160-8

Leineweber, C., Chungkham, H.S., Lindqvist, R., Westerlund, H., Runesdotter, S., Smeds Alenius, L., dan Tishelman, C. 2016. 'Nurses' Practice Environment and Satisfaction with Schedule Flexibility is Related to Intention to Leave due to Dissatisfaction: A Multi-Country, Multilevel Study". International Journal of Nursing Studies, 58, 47-58. http://doi. org/10.1016/j.jjnurstu.2016.02.003

Lieder, A., Moeke, D., Koole, G., dan Stolletz, R. 2015. "Task Scheduling in LongTerm Care Facilities: A Client-Centered Approach". Operations Research for Health Care, 6, 11-17. http://doi. org/10.1016/j.orhc.2015.06.001

Lin, C., Kang, J., Chiang, D., dan Chen, C. 2015. "Nurse Scheduling with Joint Normalized Shift and Day-Off Preference Satisfaction Using A Genetic Algorithm with Immigrant Scheme". International Journal of Distributed Sensor Networks, 2015, 1-10. http://doi. org/10.1155/2015/595419

MacLeod, L. 2012. "A Broader View of Nursing Leadership: Rethinking Manager-Leader Functions". Nurse Leader, 10(3), 57-61. http://doi.org/10.1016/j.mnl.2011.10.003

Maenhout, B. dan Vanhoucke, M. 2009. "The Impact of Incorporating Nurse-Specific Characteristics in A Cyclical Scheduling 
Approach". Journal of the Operational Research Society, 60(12), 1683-1698. http://doi.org/10.1057/jors.2008.131

Marcella-Brienza, S. dan Mennillo, T. 2015.

"Back to Work: Manager Support of Nurses With Chronic Sorrow". Creative Nursing, 21(4), 206-210. Retrieved from http://ovidsp.ovid.com/ovidweb.cgi?T=J S\&PAGE $=$ reference $\& D=$ med $\& N E W S=$ $N \& A N=26731918$

Marquis, B. L. dan Huston, C.J. 2012. Leadership Roles and Management Functions in Nursing: Theory and Application. Wolters Kluwer Health| Lippincott Williams \& Wilkins, Philadelphia.

Miltner, R.S., Jukkala, A., Dawson, M.A., dan Patrician, P.A. 2015. "Professional Development Needs of Nurse Managers". Journal of Continuing Education in Nursing, 46(6), 252-258 7p. http://doi. org/10.3928/00220124-20150518-01

Miyata, C., Arai, H., dan Suga, S. 2015. "Characteristics of the Nurse Manager's Recognition Behavior and Its Relation to Sense of Coherence of Staff Nurses in Japan". Collegian, 22(1), 9-17. http:// doi.org/10.1016/j.colegn.2013.10.004

Mokoka, E., Oosthuizen, M. J., dan Ehlers, V. J. 2010. "Retaining Professional Nurses in South Africa: Nurse Managers' Perspectives". Health SA Gesondheid, 15(1), 1-9. http://doi.org/10.4102/hsag. v15i1.484

Moore, A. dan Waters, A. 2012. "Getting Ratios Right, for the Patients' Sake". Nursing Standard, 26(31), 16-9. http:// doi.org/10.7748/ns2012.04.26.31.16. p8021

Nelson, M. F. dan Tarpey, R.J. 2010. “Work Scheduling Satisfaction and Work Life Balance for Nurses: The Perception of Organizational Justice". Academy of
Health Care Management Journal, 6(1), 25-36.

Numminen, O., Leino-Kilpi, H., Isoaho, H., dan Meretoja, R. 2015. "Newly Graduated Nurses' Competence and Individual and Organizational Factors: A Multivariate Analysis". Journal of Nursing Scholarship, 47(5), 446-457. http://doi. org/10.1111/jnu.12153

Okonkwo, E. 2014. "Flexible Work Hour and Tenure Impacts on Time-based Work Interference with Family". IFE Psychologia: An International Journal, 22(1), 232-238.

Robbins, S. P. dan Judge, T. A. 2013. Organizational Behavior (15 th). Pearson Education, New Jersey.

Satu, K., Leena, S., Mikko, S., Riitta, S., dan Helena, L. 2013. "Competence Areas of Nursing Students in Europe". Nurse Education Today, 33(6), 625-632. http:// doi.org/10.1016/j.nedt.2013.01.017

Schwarzkopf, R., Sherman, R. O., dan Kiger, A.J. 2011. "Taking Charge: FrontLine Nurse Leadership Development". The Journal of Continuing Education in Nursing, 43(4), 154-159. http://doi. org/10.3928/00220124-20111101-04

Simunić, A. dan Gregov, L. 2012. "Conflict between Work and Family Roles and Satisfaction among nurses in Different Shift Systems in Croatia: A Questionnaire Survey". Arhiv Za Higijenu Rada I Toksikologiju, 63(2), 189-97. http://doi. org/10.2478/10004-1254-63-2012-2159

Stimpfel, A.W., Brewer, C.S., dan Kovner, C. T. 2015. "Scheduling and Shift Work Characteristics Associated with Risk for Occupational Injury in Newly Licensed Registered Nurses: An Observational Study". International Journal of Nursing Studies, 52(11), 1686-1693. http://doi. org/10.1016/j.ijnurstu.2015.06.011 
Takase, M., Nakayoshi, Y., Yamamoto, Van Den Bergh, J., Beliën, J., De Bruecker, M., Teraoka, S., dan Imai, T. $2014 . \quad$ P., Demeulemeester, E., dan De Boeck, "Competence Development as Perceived L. 2013. "Personnel Scheduling: A by Degree and Non-Degree Graduates Literature Review". European Journal of in Japan: A Longitudinal Study". Nurse Education Today, 34(3), 451-456. http:// doi.org/10.1016/j.nedt.2013.04.017 Operational Research, 226(3), 367-385. http://doi.org/10.1016/j.ejor.2012.11.029

Trinkoff, A.M., Johantgen, M., Storr, C. L., Gurses, A.P., Liang, Y., dan Han, K. 2011. Nurses' work Schedule Characteristics, Nurse Staffing, and Patient Mortality". Nursing Research, 60(1), 1-8. http://doi. org/10.1097/NNR.0b013e3181fff15d

Tsaia, C.C. dan Leeb, C. J. 2010. "ptimization of Nurse Scheduling Problem with a Two-Stage Mathematical Programming Model". Asia Pacific Management Review, 15(4), 503-516.

Whitehead, D.K., Weiss, S.A., dan Tappen, R.M. 2007. Essentials of Nursing Leadership and Management. 5th ed. F.A. Davis Company, United States. http://doi. org/10.1017/CBO9781107415324.004

Wright, P.D. dan Mahar, S. 2013. Centralized Nurse Scheduling to Simultaneously Improve Schedule Cost and Nurse Satisfaction. Omega (United Kingdom), 41(6), 1042-1052. http://doi. org/10.1016/j.omega.2012.08.004. 